\title{
PEMANFAATAN PELAYANAN INFORMASI PASAR OLEH PETANI DAN PEDAGANG KUBIS BUNGA : Kasus di Kecamatan Lembang, Kabupaten Bandung
}

\author{
Hepi Hapsari ${ }^{1}$, Ronnie S. Natawidjaja, Yuni Astuti \\ Jurusan Sosial Ekonomi, Fakultas Pertanian UNPAD \\ ${ }^{1}$ e-mail: hapsari.hepi@yahoo.co.id
}

\begin{abstract}
ABSTRAK. Tujuan penelitian ini adalah mengetahui karakteristik informasi yang dibutuhkan petani dan pedagang kubis bunga. Penelitian menggunakan metode survei dengan analisis data secara deskriptif dan uji Augmented Dickey-Fuller (ADF). Hasil penelitian menunjukkan bahwa sumber, isi, media dan frekuensi penyampaian informasi PIP sesuai dengan keinginan petani dan pedagang. Namun informasi harga yang disajikan PIP tidak dimanfaatkan oleh petani dan pedagang. Petani menggunakan informasi harga dari pedagang pengumpul. Pedagang pengumpul memperoleh informasi dari pedagang besar. Pedagang besar memperoleh informasi dari loper (pengecer). Informasi harga PIP cenderung lebih tinggi dari harga faktual yang terjadi di pasar. Faktor-faktor yang mempengaruhi petani dan pedagang tidak menggunakan informasi harga PIP karena (1) kesenjangan harga PIP dengan harga pasar faktual, (2) publikasi melalui papan harga dan surat kabar sudah tidak ada lagi, (3) kurangnya pengetahuan petani dan pedagang tentang PIP.
\end{abstract}

Kata kunci: sistem informasi pasar, kubis bunga

\section{UTILIZATION OF MARKET INFORMATION SERVICE BY FARMERS AND TRADERS OF CAULIFLOWER : A Case in Kecamatan Lembang, Kabupaten Bandung}

\begin{abstract}
The aims of the study were: to understand the information characteristics needed by farmers and traders; to find out the factors that cause farmers and traders use or not to use the information; and to verify the quality of information provided by the MIS. A survey research method was used in this study. A descriptive analysis was applied in the study where the data collected was analyzed through tabulation and Augmented Dickey-Fuller (ADF) test. The result of this study indicates that the information needed by farmers and traders of cauliflower have the same characteristic with the information provided by the MIS. Even though that, price information from the MIS was not used by farmers and traders, because they mostly got information from a personal communication, either from other farmers or traders, of cauliflower. For some reasons, those information were considered to be more reliable. Factors that prevent farmers from using the price information provided by the MIS were: due to a previous bad
\end{abstract}


Pemanfaatan Pelayanan Informasi Pasar Oleh Petani dan Pedagang Kubis Bunga: Kasus di Kecamatan Lembang, Kabupaten Bandung (Hepi Hapsari, Ronnie S. Natawidjaja, Yuni Astuti)

experience when doing a transaction, Cauliflower selling price received by the farmers tend to be lower than price information from MIS; Information media like bulletin board and newspaper were no longer used as a publication media; and lack of farmers knowledge how to use the information.

Key words: market information system, cauliflower (B.O.L. cauliflower DC)

\section{PENDAHULUAN}

Kurangnya informasi pasar menimbulkan fluktuasi harga dan perbedaan harga yang cukup besar antara daerah yang satu dengan daerah yang lain. Konsekuensi dari situasi seperti ini adalah besarnya risiko usaha dan turunnya gairah berproduksi para petani. Kelangkaan informasi pasar juga mengakibatkan turunnya kekuatan tawar-menawar petani (Zehrfeld, 1980).

Untuk menanggulangi hal tersebut Direktorat Bina Usaha dan Pengolahan Hasil Tanaman Pangan, Departeman Pertanian mengadakan Pelayanan Informasi Pasar (PIP). PIP ini merupakan proyek kerjasama teknis antara pemerintah Jerman dan Indonesia, yaitu Agricultural Technical Assistance pada tahun 1985/1986 (ATA 85/86) yang berada dalam lingkungan Direktorat Jendral Pertanian Tanaman Pangan. Tujuan didirikannya PIP adalah untuk membentuk suatu Pelayanan Informasi Pasar Hasil-Hasil Pertanian secara nasional. Sebagai langkah pertama adalah dikembangkannya suatu sistem informasi harga sayur-mayur dataran tinggi.

Informasi harga hasil pertanian adalah suatu kegiatan mengumumkan harga sayur-mayur setiap hari. Sasaran dari kegiatan ini adalah petani dan pedagang. Informasi pasar hasil-hasil pertanian bertujuan untuk meningkatkan pengetahuan semua pihak terhadap perkembangan pasar, untuk mencapai tujuan meningkatkan efisiensi pemasaran hasil-hasil pertanian di Indonesia. Informasi harga memberi pilihan yang lebih banyak bagi pedagang dalam melakukan pembelian dan penjualan ke daerah lain sesuai dengan harga yang diumumkan serta membantu petani memperbaiki posisi dalam menghadapi pedagang dan kedua belah pihak dapat lebih memberikan kepastian tentang perkembangan harga yang dapat membantu mengurangi kerugian dalam jual beli (Direktorat Bina Usaha dan Pengolahan Hasil, 1990).

Permasalahan muncul ketika kenyataan di lapangan menunjukkan bahwa informasi pasar belum dimanfaatkan secara optimal oleh petani maupun pedagang. Petani kurang mempercayai informasi harga dari PIP karena informasi tersebut tidak dapat digunakan oleh petani untuk melakukan transaksi jual beli dengan pedagang. Pedagangpun tidak menyukai jika petani berpedoman pada informasi harga dari PIP. Padahal isi informasi harga dari PIP lebih baik dan konsisten secara statistik dengan harga yang berlaku di pasar lokal (Natawidjaja, 1996). Informasi harga dari PIP cenderung lebih banyak digunakan oleh pedagang untuk mengeruk keuntungan. Mereka tidak mau membeli produk hasil pertanian dari petani sesuai dengan harga yang mereka ketahui dari PIP. Informasi tersebut 
hanya mereka gunakan untuk meningkatkan posisi tawar-menawar mereka dengan pedagang yang lebih besar.

Berdasarkan latar belakang dan permasalahan yang dijelaskan sebelumnya, maka penelitian ini bertujuan untuk :

(1) Mengetahui karakteristik informasi yang dibutuhkan oleh petani dan pedagang kubis bunga

(2) Mendeskripsikan pemanfaatan informasi harga dari PIP oleh petani dan pedagang kubis bunga dalam penentuan harga jual.

(3) Membuat keragaan alasan petani dan pedagang kubis bunga dalam menggunakan informasi harga dari PIP.

(4) Menguji kualitas informasi harga kubis bunga yang dilaporkan oleh PIP.

\section{METODE PENELITIAN}

Metode yang digunakan adalah survei dengan pemilihan sampel untuk petani kubis bunga dilakukan secara sistematik (Systematic Sampling). Penarikan contoh sistematik menurut Dergibson (2000) adalah suatu teknik penarikan contoh yang dilakukan dengan cara memilih unit pertama sebagai anggota contoh secara acak, sedangkan pemilihan unit-unit berikutnya ditentukan secara sistematik menurut waktu, urutan atau lokasi. Pengambilan data untuk karakteristik informasi yang dibutuhkan, pemanfaatan informasi harga dan faktor-faktor yang mempengaruhi keputusan petani dalam menggunakan informasi harga dilakukan berdasarkan lokasi dan waktu. Lokasi penelitian di Kecamatan Lembang pada tahun 2002. Pengambilan data setiap Senin - Minggu, pukul 07.00 - 12.00 WIB dengan asumsi bahwa jam-jam tersebut merupakan jam kerja petani di lahan dan waktu pedagang melakukan pembelian kubis bunga.

Populasi petani sebanyak 1422 orang dan diambil sampel sebanyak 30 orang. Jumlah sampel tersebut berdasarkan pada asumsi normalitas, yang menyatakan bahwa minimal 30 sampel dari suatu populasi besar, maka sampel tersebut dianggap telah mengikuti sebaran normal sehingga dapat mewakili karakteristik populasi (Gasperz, 1991).

Pengambilan responden untuk pedagang pengumpul sebanyak 10 orang maupun pedagang besar sebanyak 3 orang dilakukan secara sensus. Sensus menurut Supranto (1990) yaitu pencatatan secara menyeluruh terhadap elemenelemen yang menjadi objek penelitian. Cara sensus digunakan karena jumlah pedagang kubis bunga yang tidak terlalu banyak.

Cara pengambilan data harga mengikuti ketentuan dari Dinas Pertanian Tanaman Pangan dan Hortikultura. Data diperoleh dengan mewawancarai petani atau pedagang kubis bunga. Data harga yang dikumpulkan yaitu harga kubis bunga dari 3 responden, dimana responden ditingkat produksi adalah petani kubis bunga yang melakukan penanaman pada bulan Mei -Juni dan panen pada bulan Agustus - Oktober dan pedagang yang membeli kubis bunga dari petani pada 
Pemanfaatan Pelayanan Informasi Pasar Oleh Petani dan Pedagang Kubis Bunga: Kasus di Kecamatan Lembang, Kabupaten Bandung (Hepi Hapsari, Ronnie S. Natawidjaja, Yuni Astuti)

bulan Agustus - Oktober 2002. Pengambilan data harga dilakukan setiap hari kerja yaitu hari Senin sampai hari Jum'at pada pukul 06.30 - 12.00 WIB selama 40 hari.

Data harga yang didapat dihitung rata-ratanya dengan menggunakan metode rata-rata tanpa ekstrim. Untuk mengetahui kualitas informasi harga dari PIP digunakan analisis ekonometrik time series dengan model regresi yang digunakan Natawidjaja R.S (1996).

$P=\beta P_{P I P}+\mu_{t}$

dimana :

$$
\begin{array}{ll}
\mathrm{P} & =\text { Harga rata-rata kubis bunga saat penelitian } \\
\mathrm{P}_{\mathrm{PIP}} & =\text { Harga kubis bunga harian yang dilaporkan oleh PIP } \\
\mu_{\mathrm{t}} & =\text { Arah dari perbedaan harga kubis bunga dari PIP dengan } \\
& \text { harga kubis bunga pada saat penelitian } \\
\beta & =\text { koefisien kointegrasi }
\end{array}
$$

Jika $\beta=1$ artinya variasi harga PIP dapat menjelaskan $100 \%$ variasi harga yang terjadi di lapangan. Untuk menilai signifikansi dari koefisien kointegrasi $(\beta)$, digunakan pengujian statistik dengan Augmented Dickey - Fuller (ADF).

$\Delta \mu_{\mathrm{t}}=\phi \mu_{\mathrm{t}-1}+\sum_{i=1}^{p} b i \Delta \mu_{\mathrm{t}-1}+\varepsilon_{\mathrm{t}}$

Dimana: $\phi \quad=$ koefisien Dickey-Fuller,

$\mu_{\mathrm{t}} \quad=$ Residual,

$\mu_{\mathrm{t}-1} \quad=$ Lag residual,

$\Delta \mu_{\mathrm{t}} \quad=$ Difference dari residual,

$\Delta \mu_{\mathrm{t}-1}=$ Difference dari lag residual,

$\mathrm{P} \quad=$ Panjang struktur lag.

$P=1$ dengan asumsi bahwa dengan panjang struktur lag sama dengan satu data dianggap sudah stasioner.

\section{HASIL DAN PEMBAHASAN}

Karakteristik Informasi yang Dibutuhkan oleh Petani dan Pedagang Kubis Bunga

\section{Sumber Informasi}

Seluruh responden menyatakan bahwa mereka membutuhkan informasi harga sebagai salah satu patokan untuk melakukan transaksi jual beli sayur-mayur. Bagi petani informasi harga ini digunakan untuk memperoleh kepastian bahwa harga sayur-mayur yang mereka jual cukup layak dan sesuai dengan yang berlaku di pasar, sehingga mereka tidak merasa dibohongi oleh pedagang yang membeli hasil panennya. 
Tabel 1. Sumber informasi yang digunakan responden.

\begin{tabular}{|c|c|c|c|c|c|c|}
\hline \multirow[t]{2}{*}{$\begin{array}{l}\text { Sumber informasi } \\
\text { yang digunakan }\end{array}$} & \multicolumn{2}{|c|}{ Petani } & \multicolumn{2}{|c|}{$\begin{array}{l}\text { Pedagang } \\
\text { Pengumpul }\end{array}$} & \multicolumn{2}{|c|}{ Pedagang Besar } \\
\hline & Eorang & $\%$ & Eorang & $\%$ & Eorang & $\%$ \\
\hline Petani & 9 & 30 & - & - & - & - \\
\hline P. Pengumpul & 14 & 46,67 & 2 & 20 & - & - \\
\hline P. Besar & 7 & 23,33 & 8 & 80 & - & - \\
\hline Loper & - & - & - & - & 3 & 100 \\
\hline & - & - & - & - & - & - \\
\hline Jumlah & 30 & 100 & 10 & 100 & 3 & 100 \\
\hline
\end{tabular}

Informasi harga yang digunakan oleh petani umumnya berasal dari pedagang pengumpul. Meskipun ada tawar menwar harga dalam proses transaksi jual beli, pada akhirnya pedagang pengumpul yang menentukan harga akhir. Petani tidak bisa berbuat banyak dan hanya pasrah menerima keputusan pedagang karena petani beranggapan selain pedagang tersebut yang merupakan langganannya siapa lagi yang akan membeli hasil panennya itu. Ini merupakan salah satu indikasi bahwa posisi tawar-menawar petani sangat lemah jika dibandingkan dengan pedagang pengumpul.

Selain menggunakan informasi harga dari pedagang pengumpul dan pedagang besar adapula petani yang menggunakan informasi harga dari sesama petani yang telah menjual usahataninya. Mereka mempercayai informasi tersebut karena mereka beranggapan bahwa sesama petani yang merupakan teman, tetangga ataupun saudara tidak akan membohonginya. Mereka tidak mempercayai informasi harga dari pedagang karena pedagang seringkali berbohong tentang harga yang terjadi di pasar tujuan kecuali jika pedagang tersebut memperlihatkan nota dari pedagang penerima di pasar tujuan (Cibitung atau PIKJ).

Bagi pedagang pengumpul, informasi harga merupakan salah satu cara untuk dapat memperoleh keuntungan yang lebih besar. Dengan adanya informasi harga mereka dapat menetapkan harga beli berdasarkan harga yang terendah ditawarkan di kalangan pedagang-pedagang dan dapat mencari lokasi petani yang memiliki harga jual yang terendah. Setelah memperhitungkan biaya-biaya lain yang harus dikeluarkannya, seperti transportasi dan bongkar muat barang. Pedagang pengumpul memperoleh informasi harga dari sesama pedagang yang telah melakukan pembelian. Namun ada pula yang mendapatkan informasi harga dari para bandar yang menjadi langganan mereka. Pada umumnya pedagang akan menggunakan informasi dari pedagang yang lebih tinggi tingkatannya.

Pedagang besar/bandar mempunyai jaringan informasi sendiri. Mereka mendapatkan informasi tentang harga sayur-mayur dari loper. Loper yaitu pedagang pengecer di pasar tujuan yang menerima sayur-mayur yang dikirim oleh pedagang besar. Informasi tersebut dapat mereka ketahui melalui telepon atau 
Pemanfaatan Pelayanan Informasi Pasar Oleh Petani dan Pedagang Kubis Bunga: Kasus di Kecamatan Lembang, Kabupaten Bandung (Hepi Hapsari, Ronnie S. Natawidjaja, Yuni Astuti)

dari pekerjanya yang telah mengantarkan sayur-mayur ke pasar tujuan. Berdasarkan informasi inilah mereka menentukan harga sayur-mayur yang akan mereka beli baik dari pedagang pengumpul maupun dari petani langsung.

\section{Isi Informasi}

Informasi dapat menciptakan suatu situasi di mana pemakai informasi tersebut harus melakukan pemilihan kemungkinan. Jika seseorang sadar dan merasakan adanya kebutuhan atau masalah maka ia akan berusaha mencari keterangan mengenai hal-hal baru yang dapat memenuhi kebutuhannya. Kesadaran akan adanya informasi dapat mendorong mencari informasi lebih banyak tentang hal-hal yang dapat memenuhi kebutuhannya.

Petani lebih membutuhkan informasi harga yang terjadi di pasar produsen, dengan alasan informasi harga tersebut dapat mereka jadikan sebagai patokan harga jual dengan catatan informasi harga tersebut sama dengan harga yang terjadi di lapangan pada saat mereka menjual hasil usahataninya.

Pedagang pengumpul membutuhkan informasi harga yang terjadi di pasar konsumen. Informasi tersebut dapat mereka jadikan patokan dalam menentukan harga beli kepada petani dan juga untuk memilih ke pedagang besar mana mereka akan menjual sayur-mayurnya. Mereka akan memilih pedagang besar yang menjual sayur-mayurnya ke pasar konsumen yang harga jualnya paling tinggi.

Tabel 2. Informasi yang dibutuhkan responden.

\begin{tabular}{|c|c|c|c|c|c|c|}
\hline \multirow{2}{*}{$\begin{array}{c}\text { Informasi yang } \\
\text { dibutuhkan }\end{array}$} & \multicolumn{2}{|c|}{ Petani } & \multicolumn{2}{|c|}{ P. Pengumpul } & \multicolumn{2}{|c|}{$\begin{array}{c}\text { Pedagang } \\
\text { Besar }\end{array}$} \\
\hline & Lorang & $\%$ & Eorang & $\%$ & Eorang & $\%$ \\
\hline Harga pasar produsen & 18 & 60 & 1 & 10 & - & - \\
\hline Harga pasar tujuan & 8 & 26,67 & 8 & 80 & - & - \\
\hline Daya serap pasar & 4 & 13,33 & 1 & 10 & 3 & 100 \\
\hline Jumlah & 30 & 100 & 10 & 100 & 3 & 100 \\
\hline
\end{tabular}

Pedagang besar membutuhkan informasi tentang daya serap pasar. Mereka beralasan dengan mengetahui daya serap pasar mereka dapat mengetahui berapa besar volume sayur-mayur yang akan mereka kirimkan dan pasar mana yang dapat menampung sayur-mayurnya dalam kapasitas yang besar.

\section{Media Penyampaian}

Media massa sebagai media komunikasi dapat dijadikan sebagai salah satu alat untuk menyebarluaskan informasi, namun media massa mempunyai keterbatasan dalam membawakan pesan. Seperti yang dikemukakan oleh Astrid S. Susanto (1979) bahwa pesan melalui media massa mungkin sampai, akan tetapi 
kemungkinan besar adalah bahwa isi dari pesan tidak dapat dipahami, untuk itu diperlukan suatu interpretasi orang yang memahami isi pesan tersebut.

Media publikasi yang diminati oleh petani adalah papan harga. Alasannya adalah melalui papan harga mereka dapat memperoleh informasi tanpa mengeluarkan biaya, asalkan papan harga tersebut berada di tempat-tempat yang dekat atau mudah dijangkau dengan jalan kaki. Pedagang pengumpul pada umumnya menyukai koran dan radio sebagai alat penyebaran informasi, karena dengan berlangganan koran yang diantarkan tiap hari oleh pedagang koran atau mendengarkan radio mereka sekaligus dapat memperoleh informasi tidak hanya informasi harga tetapi informasi politik yang sedang marak dibicarakan bisa mereka dapatkan dengan membaca koran atau mendengarkan radio (Tabel 3 ).

Pedagang besar lebih menyukai koran sebagai media penyebaran informasi, alasannya mereka tidak usah repot-repot melihat papan harga untuk memperoleh informasi, tetapi cukup dengan berlangganan koran yang diantar setiap pagi, dengan begitu dapat menghemat waktu mereka.

Tabel 3. Media komunikasi yang diminati responden dalam penyebarluasan informasi harga.

\begin{tabular}{|c|c|c|c|c|c|c|}
\hline \multirow[t]{2}{*}{$\begin{array}{c}\text { Media Penyampaian } \\
\text { yang diminati }\end{array}$} & \multicolumn{2}{|c|}{ Petani } & \multicolumn{2}{|c|}{$\begin{array}{l}\text { Pedagang } \\
\text { Pengumpul }\end{array}$} & \multicolumn{2}{|c|}{ Pedagang Besar } \\
\hline & Eorang & $\%$ & Eorang & $\%$ & Eorang & $\%$ \\
\hline Koran & 5 & 36,67 & 5 & 50 & 3 & 100 \\
\hline Papan Harga & 14 & 43,33 & - & - & - & - \\
\hline Radio & 11 & 20 & 5 & 50 & - & - \\
\hline Jumlah & 30 & 100 & 10 & 100 & 3 & 100 \\
\hline
\end{tabular}

\section{Frekuensi Penyampaian}

Frekuensi penyampaian informasi yang dibutuhkan oleh petani responden pada umumnya yaitu 2 kali. Mereka beranggapan bahwa harga sayur-mayur dalam sehari dapat berubah lebih dari satu kali. Dengan informasi harga yang dilaporkan dua kali maka petani dapat mengetahui perubahan harga yang terjadi dan waktu di mana harga sayur-mayur meningkat.

Tabel 4. Frekuensi penyampaian informasi harga yang dibutuhkan responden

\begin{tabular}{lcccccc}
\hline \multirow{2}{*}{$\begin{array}{c}\text { Frekuensi yang } \\
\text { dibutuhkan }\end{array}$} & \multicolumn{2}{c}{ Petani } & \multicolumn{2}{c}{$\begin{array}{c}\text { Pedagang } \\
\text { Pengumpul }\end{array}$} & \multicolumn{2}{c}{ Pedagang Besar } \\
\cline { 2 - 7 } & Lorang & $\%$ & $\sum$ orang & $\%$ & Lorang & $\%$ \\
\hline Satu kali & 11 & 36,67 & 3 & 30 & 3 & 100 \\
Dua kali & 18 & 60 & 7 & 70 & - & - \\
Tiga kali & 7 & 23,33 & - & - & - & - \\
\hline Jumlah & 30 & 100 & 10 & 100 & 3 & 100 \\
\hline
\end{tabular}


Pemanfaatan Pelayanan Informasi Pasar Oleh Petani dan Pedagang Kubis Bunga: Kasus di Kecamatan Lembang, Kabupaten Bandung (Hepi Hapsari, Ronnie S. Natawidjaja, Yuni Astuti)

Sebagian besar pedagang pengumpul membutuhkan informasi harga dua kali dalam satu hari karena mereka ingin mengetahui kapan harga sayur-mayur meningkat setiap harinya. Untuk pedagang besar, mereka mebutuhkan frekuensi penyampaian informasi harga dilakukan hanya satu kali dalam satu hari karena mereka mengirimkan sayur-mayur ke pasar tujuan hanya satu kali.

\section{Pemanfaatan Informasi Harga dari Pelayanan Informasi Pasar (PIP) oleh Petani dan Pedagang Kubis Bunga}

Informasi harga yang akurat dan cepat sangat penting dalam transaksi jual beli sayur mayur yang harus terjual saat itu juga. Namun ternyata tidak ada satupun petani maupun pedagang kubis bunga yang menggunakan informasi harga dari PIP. Seluruh responden sudah melupakan informasi harga dari PIP yang mereka ketahui melalui siaran radio atau papan harga. Petani menyatakan bahwa mereka pernah menggunakan informasi harga dari PIP tapi sudah lama mereka tidak menggunakannya lagi. Mereka beranggapan bahwa informasi harga dari PIP yang mereka dapatkan melalui siaran radio ataupun papan harga tidak dapat dijadikan patokan dalam penentuan harga jual untuk kubis bunga yang mereka hasilkan. Pedagang baik pedagang pengumpul maupun pedagang besar tidak mau membeli kubis bunga dari petani sesuai dengan harga PIP dengan alasan bahwa harga PIP tersebut merupakan harga di pasar tujuan atau bahkan harga PIP lebih tinggi dibandingkan dengan harga yang terjadi di pasar tujuan.

Seluruh responden tidak mengetahui telah terjadi perubahan jadwal siaran informasi harga PIP di radio. Mereka mendengarkan radio untuk mendapatkan hiburan dan berita-berita lainnya yang sedang hangat dibicarakan seperti politik dan ekonomi bukan informasi harga. Media penyampaian informasi harga PIP yang lainnya yaitu koran dan papan harga sudah tidak digunakan oleh PIP dalam proses penyampaian informasi harga, tidak mereka ketahui. Bahkan keadaan papan harga yang sudah rusak dan tidak layak lagi untuk digunakan.

\section{Faktor-faktor yang Mempengaruhi Petani dan Pedagang Kubis Bunga Tidak Menggunakan Informasi Harga dari PIP}

Pemanfaatan informasi harga oleh petani dan pedagang kubis bunga tidak terlepas dari berbagai hal termasuk faktor dalam dirinya sendiri. Faktor dari diri sendiri merupakan karakteristik petani dan pedagang kubis bunga yang dapat menjadi faktor penghambat maupun pendorong untuk pemanfaatan informasi harga baik dari PIP maupun dari komunikasi pribadi. Karakteristik responden diantaranya yaitu kebutuhan akan informasi harga, pengalaman responden, umur responden dan tingkat pendidikan. Faktor lain yang dapat mempengaruhi pemanfaatan informasi harga diantaranya waktu informasi harga dibutuhkan. 


\section{Kebutuhan responden akan informasi harga}

Kebutuhan responden akan informasi harga meliputi kebutuhan sebatas mengetahui, untuk membandingkan harga yang ada dan sebagai pedoman untuk melakukan transaksi. Seluruh responden menyatakan membutuhkan informasi harga yang dapat dijadikan pedoman untuk menentukan harga jual hasil produksinya untuk petani dan menentukan harga beli untuk pedagang. Bila tidak ada informasi harga yang dapat dijadikan pedoman sebagai bahan penentuan harga jual maka pedagang dapat mempermainkan harga yang akan diterima petani.

Dengan adanya kebutuhan akan informasi harga, maka responden akan mencari informasi tersebut untuk memenuhi kebutuhannya. Informasi yang mereka cari dan mereka gunakan yaitu informasi harga yang mereka dapat dari komunikasi pribadi. Komunikasi pribadi ini merupakan komunikasi yang mereka lakukan sehari-hari karena adanya interaksi antara satu dengan yang lainnya. Mereka lebih mempercayai informasi tersebut karena informasi harga yang mereka dapatkan itu sesuai dengan harga yang terjadi pada saat mereka melakukan transaksi jual-beli.

\section{Pengalaman Responden}

Pengalaman usahatani maupun berdagang tidak mempengaruhi responden dalam memilih informasi harga yang mereka gunakan. Seluruh responden mengambil keputusan untuk memanfaatkan informasi harga yang berasal komunikasi pribadi. Informasi harga dari PIP tidak dipilih karena informasi tersebut tidak memuaskan responden. Petani cenderung menggunakan informasi yang mereka dapat dari pedagang pengumpul, sedangkan lebih dari $50 \%$ pedagang pengumpul yang menggunakan informasi dari pedagang besar dan pedagang besar seluruhnya menggunakan informasi yang mereka dapat dari loper. Informasi harga PIP berbeda dengan kenyataan yang dihadapi petani di lapangan pada saat melakukan transaksi jual-beli.

\section{Tingkat Pendidikan Responden}

Tingkat pendidikan responden tidak mempengaruhi dalam mengambil keputusan untuk memanfaatkan informasi harga. Pada semua tingkat pendidikan rendah maupun tinggi, seluruh responden menggunakan informasi dari komunikasi pribadi yang terjadi baik antara sesama petani, sesama pedagang maupun antara petani dan pedagang. Responden lebih menggunakan informasi yang berasal dari komunikasi pribadi karena lebih sesuai dengan harga yang terjadi di lapangan. 
Pemanfaatan Pelayanan Informasi Pasar Oleh Petani dan Pedagang Kubis Bunga: Kasus di Kecamatan Lembang, Kabupaten Bandung (Hepi Hapsari, Ronnie S. Natawidjaja, Yuni Astuti)

Waktu Informasi Harga Dibutuhkan oleh Responden

Petani membutuhkan informasi harga pada saat akan memanen hasil produksinya. Mereka akan melakukan panen setelah mereka mengetahui keadaan harga yang terjadi di lapangan. Mereka akan melakukan penundaan masa panen jika mereka merasa bahwa harga yang terjadi di lapangan sangat rendah, tetapi karena produk pertanian mudah rusak dan mudah busuk maka mereka tidak dapat menunda panen terlalu lama, pada akhirnya mereka akan menjual hasil panennya dan menerima harga yang terjadi pada saat itu.

Tabel 5. Waktu responden membutuhkan informasi harga.

\begin{tabular}{|c|c|c|c|c|c|c|}
\hline \multirow{2}{*}{$\begin{array}{l}\text { Waktu informasi } \\
\text { harga dibutuhkan }\end{array}$} & \multicolumn{2}{|c|}{ Petani } & \multicolumn{2}{|c|}{$\begin{array}{l}\text { Pedagang } \\
\text { Pengumpul }\end{array}$} & \multicolumn{2}{|c|}{ Pedagang Besar } \\
\hline & Eorang & $\%$ & Eorang & $\%$ & Eorang & $\%$ \\
\hline Panen & 20 & 66,67 & - & - & - & - \\
\hline Penjualan & 10 & 33,33 & - & - & - & - \\
\hline Membeli kubis & - & - & 10 & 100 & 3 & 100 \\
\hline Jumlah & 30 & $\begin{array}{r}10 \\
0\end{array}$ & 10 & 100 & 3 & 100 \\
\hline
\end{tabular}

Pedagang pengumpul dan pedagang besar membutuhkan informasi harga pada saat mereka akan membeli kubis bunga dari petani untuk pedagang pengumpul, dan membeli kubis bunga dari pedagang pengumpul untuk pedagang besar. Informasi harga yang mereka ketahui itu berfungsi sebagai patokan dalam menentukan harga beli. Dalam memenuhi kebutuhannya akan informasi, baik petani maupun pedagang kubis bunga menggunakan informasi yang berasal dari komunikasi pribadi bukan informasi yang berasal dari PIP.

Pengalaman berusaha, tingkat pendidikan, dan waktu informasi harga diperlukan, bukan merupakan faktor penghambat maupun faktor pendorong dalam pemanfaatan informasi harga dari PIP. Informasi harga dari PIP tidak dimanfaatkan karena pengalaman petani dan pedagang kubis bunga yang kurang baik dalam memanfaatkan informasi harga dari PIP. Petani dan pedagang kubis bunga pernah menggunakan informasi harga dari PIP, namun informasi harga tersebut tidak sesuai dengan harga yang mereka dapat pada saat transaksi dilakukan.

Tidak dipakainya koran dan papan harga sebagai media informasi merupakan salah satu faktor penghambat kemanfaatan informasi harga dari PIP. Radio merupakan satu-satunya media yang digunakan PIP dalam proses penyebaran informasi. Radio yang dipilih oleh PIP dalam menyiarkan informasi harga yaitu RRI. RRI menyiarkan informasi harga dua kali dalam seminggu, sedangkan petani dan pedagang membutuhkan informasi harga setiap kali mereka akan transaksi. Jual beli sayur-mayur harus secepat mungkin karena komoditas ini mudah rusak. Oleh karena itu petani dan pedagang kubis bunga lebih memilih menggunakan informasi 
harga yang mereka dapat dari hasil interaksi sehari-hari dengan petani atau atau pedagang. Dengan interaksi tersebut mereka mendapatkan informasi harga setiap saat membutuhkan.

Faktor lain yang menyebabkan informasi harga PIP tidak dimanfaatkan oleh petani dan pedagang karena mereka tidak mengetahui cara menggunakan informasi PIP yang benar. Informasi harga dari PIP akan mempunyai makna jika data yang digunakan berupa data time series atau data harga dari waktu ke waktu sehingga kita dapat memprediksikan tentang kondisi pasar. Dari data time series tersebut, dapat diketahui keadaan naik turunnya harga, sehingga petani sayurmayur dapat memprediksikan kapan panen dilakukan agar mendapatkan harga yang tinggi.

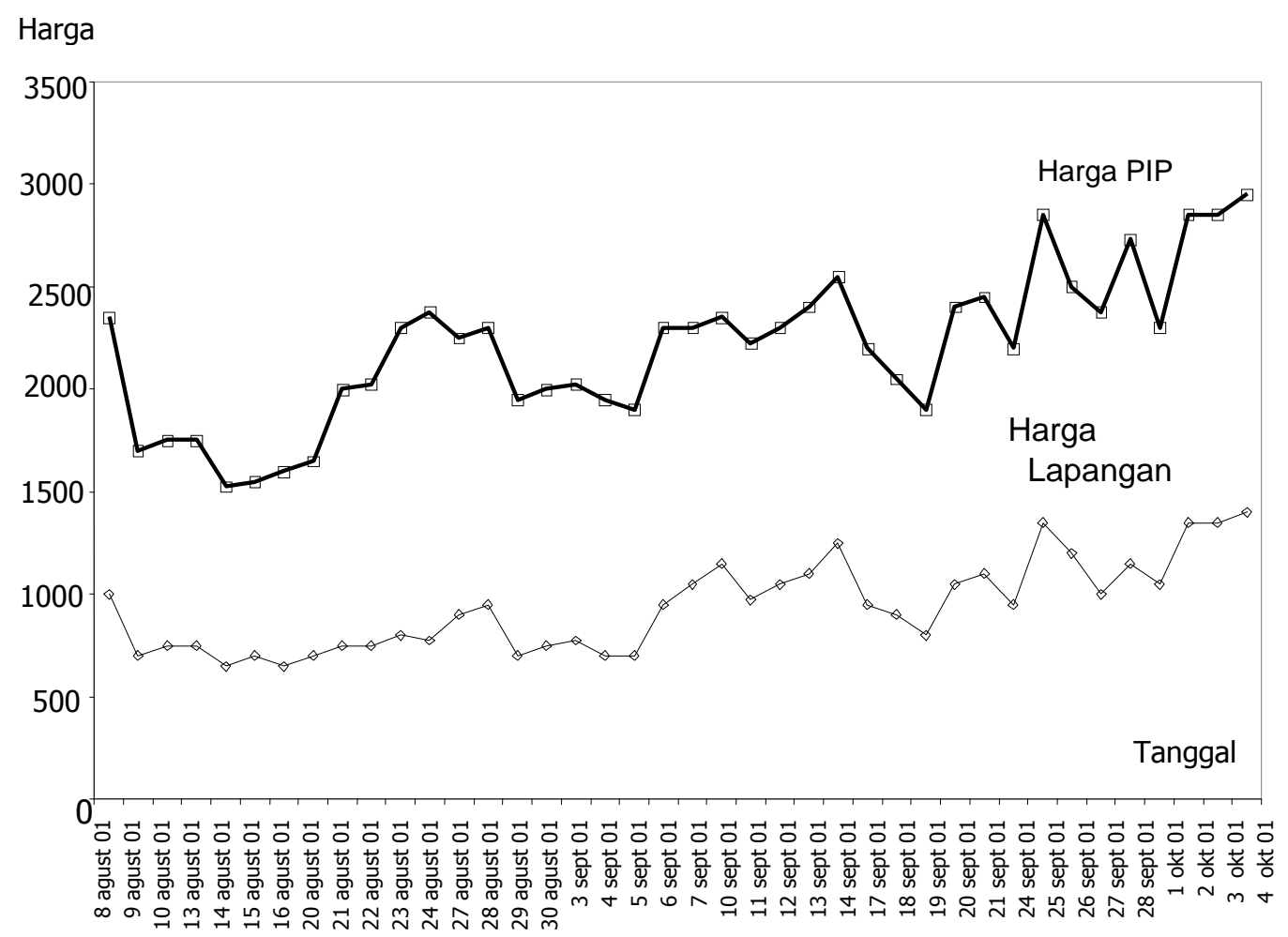

Gambar 1. Harga Kubis Bunga dari PIP dan Pada Saat Penelitian

Gambar 1 menunjukkan bahwa harga yang dilaporkan oleh PIP cenderung lebih tinggi dibandingkan dengan harga yang dikumpulkan di lapangan pada saat penelitian. Untuk menguji kualitas informasi harga PIP, yaitu sejauhmana informasi dari PIP dapat menjelaskan informasi harga yang terjadi di lapangan, digunakan analisis statistik dan uji Augmented Dickey Fuller (ADF). 
Pemanfaatan Pelayanan Informasi Pasar Oleh Petani dan Pedagang Kubis Bunga: Kasus di Kecamatan Lembang, Kabupaten Bandung (Hepi Hapsari, Ronnie S. Natawidjaja, Yuni Astuti)

Hasil perhitungan untuk persamaan (1) yaitu :

$P=-24,572+0,76 P_{P I P}$

$$
(-1,34) \quad(5,301)
$$

Nilai koefisien kointegrasi $(\beta)$ yang dihasilkan yaitu 0,76 , artinya variasi harga yang terjadi di lokasi penelitian dapat dijelaskan oleh variasi harga PIP sebesar $76 \%$. Untuk pengujian hipotesis $H_{0}$ : data bersifat non stasioner, artinya nilai koefisien kointegrasi ( $\beta$ ) pada persamaan (1) tidak mempunyai arti dalam menjelaskan variasi harga yang terjadi di lapangan. $\mathrm{H}_{1}$ : data bersifat stasioner, artinya nilai koefisien kointegrasi $(\beta)$ pada persamaan (1) mempunyai arti dalam menjelaskan variasi harga yang terjadi di lapangan.

Dari hasil perhitungan di dapat persamaan sebagai berikut :

$\Delta \mu_{\mathrm{t}}=-0,268 \mu_{\mathrm{t}-1}+0,0004346 \Delta \mu_{\mathrm{t}-1}$

$$
\begin{aligned}
& t_{\text {hitung }}=\frac{(-2,035)}{-0,268} \\
& \begin{array}{c}
-2,035 \\
t_{\text {hitung }}> \\
(0,1317)
\end{array} \begin{array}{c}
t_{\text {tabel }}, \text { yang berarti } \mathrm{H}_{0} \text { ditolak atau } \mathrm{H}_{1} \text { diterima. } \\
(-2,60)
\end{array}
\end{aligned}
$$

Hal tersebut menunjukkan bahwa variasi harga dari PIP dapat menjelaskan variasi harga yang terjadi di lapangan sebesar $76 \%$. Persentase tersebut masih harus ditingkatkan untuk dapat lebih menjelaskan keadaan harga yang terjadi di lapangan. Variasi harga PIP belum sepenuhnya dapat menjelaskan variasi harga yang terjadi di lapangan karena tempat dan waktu pengambilan data harga yang tidak sama, pengolahan data yang salah dan kualitas dari komoditas kubis bunga yang berbeda.

\section{SIMPULAN DAN SARAN}

\section{Simpulan}

1. Informasi yang dibutuhkan oleh petani dan pedagang kubis bunga di Kecamatan Lembang mempunyai karakteristik yang sama dengan informasi yang disajikan PIP.

2. Informasi harga PIP tidak dimanfaatkan oleh petani dan pedagang kubis bunga, karena tidak dapat dijadikan patokan penentuan harga jual petani atau harga beli pedagang. Petani menggunakan informasi harga dari pedagang pengumpul, pedagang pengumpul menggunakan informasi harga dari pedagang besar dan pedagang besar menggunakan informasi harga dari loper.

3. Faktor-faktor yang menyebabkan petani dan pedagang kubis bunga tidak memanfaatan informasi harga dari PIP adalah : 
- Pengalaman yang kurang baik dalam memanfaatkan informasi harga (harga yang terjadi pada saat melakukan transaksi jual beli cenderung lebih rendah dari harga yang disajikan oleh PIP).

- Media informasi PIP seperti surat kabar dan papan harga sudah tidak digunakan lagi, karena kurangnya dana untuk publikasi.

- Petani dan pedagang kubis bunga tidak mengetahui cara menggunakan informasi harga dari PIP.

4. Harga yang diinformasikan PIP cenderung lebih tinggi dibandingkan dengan harga faktual di lapangan, dengan koefisien kointegrasi $(\beta)$ sebesar 0,76 . Ini berarti variasi harga yang terjadi di lapangan dapat dijelaskan oleh variasi harga PIP sebesar 76\%. Variasi harga PIP belum sepenuhnya dapat menjelaskan variasi harga yang terjadi di lapangan, karena perbedaan tempat dan waktu pengambilan data harga, pengolahan data yang salah dan kualitas komoditas yang berbeda.

\section{Saran}

1. Perlu adanya studi normatif untuk memperbaiki kinerja PIP sesuai dengan tujuan awal berdirinya PIP.

2. Perlu dicantumkan lokasi tempat pengambilan data harga yang dijadikan basis informasi PIP, untuk menjamin harga yang dilaporkan merupakan harga yang terjadi di lokasi tersebut.

3. Perlu adanya revisi perencanaan PIP agar informasi yang disajikannya tidak terbatas pada informasi harga tetapi juga mencakup informasi pasar secara keseluruhan, seperti bentuk pasar, saluran pemasaran dan strategi pemasaran.

\section{DAFTAR PUSTAKA}

Dinas Pertanian Tanaman Pangan dan Hortikultura Propinsi Jawa Barat. (2000). Buletin Informasi Agribisnis. Bandung : Dinas Pertanian Jawa Barat.

Zehrfeld. (1980). Pelayanan Informasi Pasar Hasil-hasil Pertanian di Jawa Barat. Kerjasama Teknis Indonesia-Jerman. Jakarta : Proyek ATA 85/86-GTZ 74.2183.7.

Direktorat Bina Usaha dan Pengolahan Hasil Tanaman Pangan. (1980). Pedoman Umum Pelayanan Informasi Pasar (PIP) di Indonesia. Jakarta : Direktorat Jenderal Pertanian Tanaman Pangan.

Natawidjaja, R.S. (1996). Search and price Informastion in Agricultural in Agricultural Market: A Case Study Two Upland-Vegetable-Producer Market in Bandung County, West Java Province. PhD. Disertation. University of Hawaii, Honolulu.

Dergibson. (2000). Metode Statistik untuk Bisnis dan Ekonomi. Jakarta : PT. Gramedia Pustaka Utama. 
Pemanfaatan Pelayanan Informasi Pasar Oleh Petani dan Pedagang Kubis Bunga: Kasus di Kecamatan Lembang, Kabupaten Bandung (Hepi Hapsari, Ronnie S. Natawidjaja, Yuni Astuti)

Gasperz V. (1991). Teknik Penarikan Contoh untuk Penelitian Survei. Bandung : PT. Tarsito.

Supranto. J. (1990). Teknik Riset Pemasaran dan Ramalan Penjualan. Jakarta : PT. Rineka Cipta.

Susanto, Astrid, S. (1982). Komunikasi Massa. Bandung : PT. Bina Cipta. 